\title{
Assessment of Physico-chemical, Microbial and Phytotoxic Changes of Various Organic Wastes During their Composting Process
}

\author{
Fakher Ayed ${ }^{123} 8(D)$, , Olfa Boussadia $4(D)$, Hanem Grissa $^{2} 8(D)$ Rania Aydi Ben Abdallah ${ }^{3} 8(D)$ Hayfa \\ Jabnoun-Khiareddine ${ }^{3} \mathbf{S}$ (D) and Mejda Daami-Remadi 3 (D) \\ ${ }^{1}$ National Agronomic Institute of Tunisia, 1082 Tunis, University of Carthage, Tunisia. \\ ${ }^{2}$ Technical Centre of Organic Agriculture, 4042 Chott-Mariam, Sousse, Tunisia. \\ ${ }^{3}$ LR21AGR03-Laboratory of Production and Protection for Sustainable Horticulture (2PHD), Regional Research Centre on \\ Horticulture and Organic Agriculture, University of Sousse, 4042, Chott-Mariem, Tunisia. \\ ${ }^{4}$ Olive Tree Institute, Unit of Sousse, 4061 Sousse, Tunisia.
}

$\triangle$ Corresponding Author: akher Ayed, E-mail: ayedfakher@yahoo.fr

\section{ARTICLE INFORMATION \\ Received: August 08, 2021 \\ Accepted: September 14, 2021 \\ Volume: 2 \\ Issue: 2 \\ DOI: $10.32996 /$ jeas.2021.2.2.3}

\section{KEYWORDS}

Composting phases; microbial populations; physico-chemical traits; phytotoxicity; wastes.

\section{ABSTRACT}

In this study, the aerobic composting in windrows of five mixtures of organic materials was compared. Composting temperatures rose to $60-67^{\circ} \mathrm{C}$ within 7 to 22 days and stayed above $45^{\circ} \mathrm{C}$ for $4-5$ months before declining. Decomposition after 223 days was $40-43 \%$ for organic materials and $23-25 \%$ for carbon. The $\mathrm{pH}$ values decreased during the composting process and became neutral at maturation. Electric conductivity dropped to 3.6-5.22 mS/cm after 170 days. Dry matter increased to $96.2-97.8 \%$ within 182 days of composting and dropped to $70.13-73.87 \%$ at maturation. Bulk density increased from $0.20-0.26 \mathrm{~g} / \mathrm{cm} 3$ to $0.34-0.55 \mathrm{~g} / \mathrm{cm} 3$ and varied depending on composts. Porosity and water retention decreased during composting. Nutrient contents varied over composting times and wastes. Composts' phytotoxicity, evaluated on barley (Hordeum vulgare L.) seeds, decreased by $0.2-13.2 \%$ and $63.2-81.3 \%$ after 30 and 220 days of composting, respectively. The benefits of composting organic wastes into agriculturally valuable final products was discussed.

\section{Introduction}

The sustainability of production systems can be preserved through the adoption of farming techniques allowing stable levels of soil organic matter and the limitation of the disturbance of soil nutrient balances (Zotarelli et al., 2012). Soil fertility and quality are most commonly defined as the ability of a given soil to supply nutrients to crops in available forms and in a suitable balance (Bi et al., 2009). As these factors have been hugely affected by human activities, preserving and improving soil fertility has long been of concern to guarantee sustainable soil productivity in resource-poor as well as resource-rich countries. This may be achieved using appropriate agricultural practices such as organic amendments, frequent soil tillage, fertilizer application, crop rotation, and incorporation of crop residues into soil (Bi et al., 2009; Kong et al., 2006; Muthoni and Kabira, 2010).

In Tunisia, because of climate conditions, limited growing areas and intensive cropping on the same fields, gradual soil fertility degradation has occurred where the organic matter percentage ranged from 0 to $5.7 \%$ in most cultivated soils (Hamrouni, 2014). This degradation could be ascribed to changes in land use and the adoption of intensive soil management through repeated cultivation of soil with external inputs and disturbances (Lal, 2000). Therefore, research efforts were more focused on the development of cropping practices permitting the preservation of soil fertility to ensure soil stabilization and conservation in the mid-to-long term, and the sustainability of agricultural production in general (Creswell and Martin, 1998). Among the explored solutions, compost was used as a promising alternative to synthetic fertilizers and fungicides due to its ability to stimulate plant growth, control soilborne diseases and improve the global soil quality (Pane et al., 2013a, 2013b, 2015).

\section{K C AL-KINDI CENTER \\ $R$ D FOR RESEARCH AND}

Your gateway to world-class research

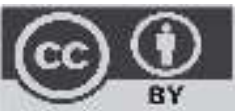

Published by Al-Kindi Center for Research and Development, London, United Kingdom. Copyright (c) the author(s). This open access article is distributed under a Creative Commons Attribution (CC-BY) 4.0 license 
On-farm composting is an environmentally safe, efficient and cost-effective process to recycle plant residues into new cropping production cycles (Maniadakis et al., 2004). It is a simple technology consisting of an aerobic bio-oxidative process, which involves the mineralization and the humification of organic matter, leading to a stabilized end-product free of a wide number of weed seeds and soilborne pests and pathogens, non phytotoxic, and with interesting humic properties (Zucconi and De Bertoldi, 1987). Compost is the final, stable and mature product derived from controlled fermentation of organic and no degraded matters with different origins such as animal wastes, crop residues, municipal and industrial wastes (Celano et al., 2012). It is a renewable organic resource that can be widely used in agricultural soils. Bio-fertilizing property of composts is attributed to their beneficial effects on physical, chemical, biological, and biochemical soil properties. Their disease suppressive effects and/or growth-promoting abilities are due to the enhancement of the plant physiological status leading to the improvement of quality and quantity of crop productions (Liguori et al., 2015; Pane et al., 2015).

In some Tunisian horticultural areas, important quantities of agricultural wastes such as animal manures, green wastes and olive (Olea europaea L.) mill solid wastes need to be valued. Thus, the objective of the current investigation was to monitor the aerobic composting process of different mixtures of organic raw materials based on various parameters (temperature, $\mathrm{pH}$, salinity, dry matter, bulk density, porosity, and water retention). The evolution of their organic matter, total organic C, N, P, K, Na and Ca contents, their microbial activity, and their phytotoxicity toward barley seeds were also monitored.

\section{Materials and methods}

\subsection{Compost production}

Composting experiments were carried out on organically certified land (Chott-Mariem, Sousse, Tunisia) with an average monthly temperature ranging from $11.4^{\circ} \mathrm{C}$ (in January) to $28^{\circ} \mathrm{C}$ (in August) and annual precipitation of $300 \mathrm{~mm}$.

Five composts, prepared from various proportions of organic starting raw materials (Table 1), were produced following openwindrow composting over a duration period of eight months (from 18 February 2017 to 28 September 2017).

Table 1. Composition of raw materials used for the tested compost windrows (\% total, w:w, the total initial mass was 10 tons per windrow).

\begin{tabular}{llllll}
\hline \multirow{2}{*}{$\begin{array}{l}\text { Compost } \\
\text { windrow }\end{array}$} & \multicolumn{2}{l}{ Raw material proportion (\%) } & & \\
\cline { 2 - 6 } & Cow manure & Chicken manure & Sheep manure & Green waste & Olive-mill solid waste \\
\hline $\mathbf{C}_{\mathbf{1}}$ & 30 & 30 & 30 & 5 & 5 \\
$\mathbf{C}_{\mathbf{2}}$ & 70 & 25 & - & - & 5 \\
$\mathbf{C}_{\mathbf{3}}$ & 70 & 25 & - & 5 & - \\
$\mathbf{C}_{\mathbf{4}}$ & 70 & - & 25 & - & 5 \\
$\mathbf{C}_{\mathbf{5}}$ & 70 & - & 25 & 5 & \\
\hline
\end{tabular}

Olive mill solid waste was obtained from traditional press olive-mills in localized in Akouda region (Sousse). Animal (cow, chicken and sheep) manures were obtained from the surrounding rural farming areas. The physical and chemical properties of these raw materials are detailed in Table 2.

Table 2. Main physical and chemical characteristics of the raw materials used in the farm experiment.

\begin{tabular}{|c|c|c|c|c|c|}
\hline \multirow[b]{2}{*}{ Traits } & \multicolumn{5}{|c|}{ Raw material used } \\
\hline & $\begin{array}{l}\text { Cow } \\
\text { manure }\end{array}$ & $\begin{array}{l}\text { Chicken } \\
\text { manure }\end{array}$ & $\begin{array}{l}\text { Sheep } \\
\text { manure }\end{array}$ & $\begin{array}{l}\text { Green } \\
\text { waste }\end{array}$ & $\begin{array}{l}\text { Olive-mill } \\
\text { solid waste }\end{array}$ \\
\hline pH & 8.12 & 7.87 & 8.5 & 5.75 & 6.28 \\
\hline Electrical conductivity $(\mathrm{mS} / \mathrm{cm})$ & 5.42 & 6.22 & 6.44 & 3 & 3.15 \\
\hline Dry matter (\%) & 75.9 & 93.06 & 94.13 & 90.43 & 89.53 \\
\hline Bulk density $\left(\mathrm{g} / \mathrm{cm}^{3}\right)$ & 0.2 & 0.29 & 0.22 & 0.12 & 0.4 \\
\hline Organic matter (\%) & 60.93 & 67.86 & 73.53 & 93.5 & 95.26 \\
\hline C (\%) & 35.42 & 39.45 & 42.75 & 54.36 & 55.38 \\
\hline
\end{tabular}

These materials were mixed separately to bring the initial approximate carbon to nitrogen (C:N) ratio of 30:1 and divided into five windrows with $1.5 \times 2.0 \times 10.0 \mathrm{~m}$ height, width, and length, respectively. Temperature and moisture were used as monitoring parameters to follow up the progress of the composting process. The internal temperature was measured daily at $50 \mathrm{~cm}$-depth at three positions along the windrow. Composts were turned mechanically to provide aeration and to improve homogeneity and water was used as a humidifying agent during all the composting period. The turning dates were marked in Figure 1 using black 
triangles (after 13, 42, 70,91, 106, 127, and 188 days). Irrigation water was added generally when the temperature decreased (1$2 \mathrm{~m}^{3}$ /windrow/irrigation).

At the end of the composting process, compost samples were collected randomly spanning the whole compost windrow at a depth of $70-90 \mathrm{~cm}$ and thoroughly mixed together. They were stored at $4^{\circ} \mathrm{C}$ for further analyses.

\subsection{Physical and chemical characterization}

During the experiment, the internal temperature was monitored daily at a depth of $50 \mathrm{~cm}$ from the surface of the compost using a probe thermometer. Nine temperature readings were taken from three points of each windrow until the end of maturation phase. The ambient temperature was also monitored. Samplings were performed at 15 days intervals during the composting process. Compost samples were taken from three points in each windrow and divided into two sub-samples.

The first sub-sample was analyzed for dry matter, bulk density, total porosity, water retention, $\mathrm{pH}$, and electrical conductivity. Dry matter content was determined by drying the sample at $105^{\circ} \mathrm{C}$ for $24 \mathrm{~h}$. The bulk density was measured based on the mass of material within a given volume (Agnew and Leonard, 2003). To express total porosity, the relationship of the volume of the open pores in the compost to its exterior volume was calculated as a percentage. $\mathrm{pH}$ and $\mathrm{EC}$ were measured in aqueous extract (using 1:5 w/v) according to ISO 10 390:2005 and ISO 11 265:1994, respectively. The second sub-sample was air-dried and used for the determination of the organic matter and the total organic carbon contents by loss-on-ignition at $550^{\circ} \mathrm{C}$ for $5 \mathrm{~h}$ (Nelson and Sommers, 1982; Reddy et al., 2005).

The mineral contents of the different composts were analyzed at the beginning and at the end of the composting process using Kjeldahl method for total nitrogen (Bremner and Mulvaney, 1982), flame photometer for potassium, calcium and sodium (MartinPrével et al., 1984) and UV-visible spectrophotometer for phosphorus (Murphy and Riley, 1962).

All laboratory analyzes were conducted in triplicate and were presented on a dry weight basis. The composting process was terminated within eight months, until the decline of compost temperatures to ambient levels and the decrease of the $\mathrm{C} / \mathrm{N}$ ratio to low values (Goyal et al., 2005).

\subsection{Microbial characterization}

Populations of filamentous fungi and bacteria were evaluated using the spread plate method. Ten grams of each compost sample were suspended in an Erlenmeyer flask containing $90 \mathrm{ml}$ of a sterile solution $\left(0.2 \%\right.$ of sodium polyphosphate $\left(\mathrm{NaPO}_{3}\right)$ in distilled water, $\mathrm{pH}$ 7.0). Each compost was ten-fold diluted $\left(10^{-2}-10^{-10}\right)$ and $100 \mu \mathrm{l}$ of each dilution were spread on the selective media. The microbial population density was analyzed on potato dextrose agar amended with streptomycin sulfate for fungi and on plate count agar for bacteria (Jouraiphy et al., 2005; Mekki et al., 2006; Pane et al., 2016). After incubation at $35^{\circ} \mathrm{C}$ (mesophile population) and $60^{\circ} \mathrm{C}$ (thermophile population), growing colonies on the culture media were counted daily for $72 \mathrm{~h}$. Colonies in plates with 30 to 300 colonies were counted and colony forming units (CFU. ${ }^{-1}$ ) were calculated as described in ISO 7218: 2007 as shown in the following formula:

$\mathrm{N}=\sum \mathrm{a} / \mathrm{Vml}\left(\mathrm{n}_{1}+0.1 \mathrm{n}_{2}\right) \mathrm{d}$

Where N: Number of colonies par gram of compost.

$\sum$ a: Sum of all of colonies in all plates counted.

$\mathrm{n}_{1}$ : Number of plates in the lower dilution counted.

$\mathrm{n}_{2}$ : Number of plates in the next higher dilution counted.

d: Dilution from which the first counts were obtained.

During the experiment, four compost samples were taken at different composting phases (mesophilic, thermophilic, cooling, and maturing phases).

\subsection{Phytotoxicity}

Barley (Hordeum vulgare L.) seeds were used for the phytotoxicity test of the composting materials. Ten seeds were sown in each pot containing only the composts during composting process, which was substituted by peat for control. The measurements were taken at different times along the composting process (after 30, 80, 125, and 220 days). Each individual treatment was replicated ten times. Seed germination was noted after 7 days under natural exposure conditions.

\subsection{Statistical analyses}

Statistical analyses were performed, for all parameters, following a completely randomized design where composts were the sole fixed factor. All parameters were subjected to one-way analyses of variance (ANOVA). Means were separated using Fisher's protected LSD or Duncan Multiple Range tests (at $P \leq 0.05$ ). Statistical analyses were performed using SPSS software version 20.

Page | 23 


\section{Results}

\section{Temperature}

Temperature evolution in the different windrow during the composting process followed the familiar pattern observed during composting (Fig. 1). In the first cycle, an initial fast increase to thermophilic temperatures above $50^{\circ} \mathrm{C}$ was recorded after 2 days and reached $60.07-67^{\circ} \mathrm{C}$ after 7-22 days. Windrows $C_{4}$ and $C_{5}$ had the longest duration of the thermophilic phase, from the $7^{\text {th }}$ to $52^{\text {th }}$ day, with the highest peaks of 61.29 and $64.59^{\circ} \mathrm{C}$, respectively, noted after 21 days. However, the highest temperatures were recorded at the $20^{\text {th }}$ day in windrow $C_{1}\left(63.33^{\circ} \mathrm{C}\right)$, the $23^{\text {th }}$ day in $C_{2}\left(60.1^{\circ} \mathrm{C}\right)$, and the $7^{\text {th }}$ day in $C_{3}\left(67^{\circ} \mathrm{C}\right)$. Other temperature peaks were noted during the composting process and occurred mainly after the turning of compost windrows. For all windrows, temperature remained above $45^{\circ} \mathrm{C}$ for about approximately $4-5$ months and declined slowly and decreased to ambient levels by the end of the composting process (Fig. 1). For all tested organic materials, the duration of the whole composting process lasted about 8 months.

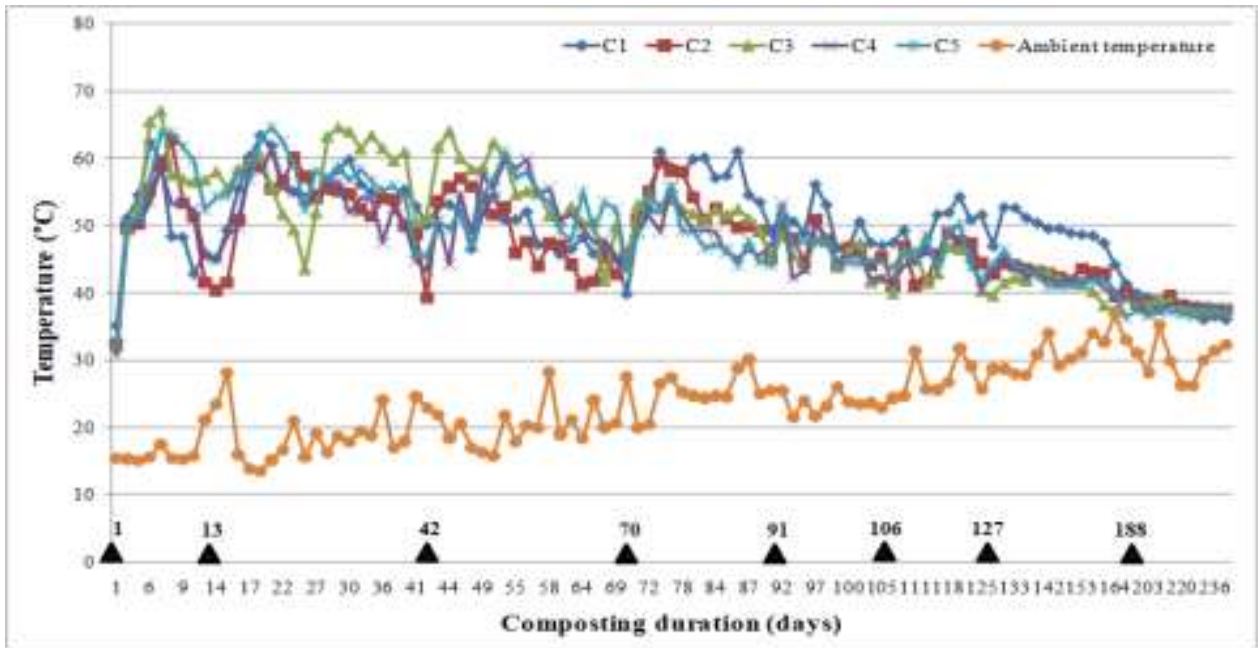

Fig. 1. Evolution of the temperature of the tested compost windrows during their composting process (Note: Triangles indicate timings of mechanical turnings).

\section{Physico-chemical characteristics}

Potential of Hydrogen $(\mathrm{pH})$

During the composting process, $\mathrm{pH}$ decreased and became steady and relatively neutral. The initial $\mathrm{pH}$ range was $8-8.51$ and decreased to 6.9 to 7.5 at the end of the thermophilic phase. Then, $\mathrm{pH}$ values stabilized at 6.83-7.37, depending on tested composts, at the end of the maturation phase (Fig. 2). $\mathrm{C}_{5}$ had the highest $\mathrm{pH}$ value (7.37) and $\mathrm{C}_{2}$ had the lowest $\mathrm{pH}$ (6.83). No significant differences were observed between $\mathrm{pH}$ values of composts $C_{1}, C_{3}$ and $C_{4}$.

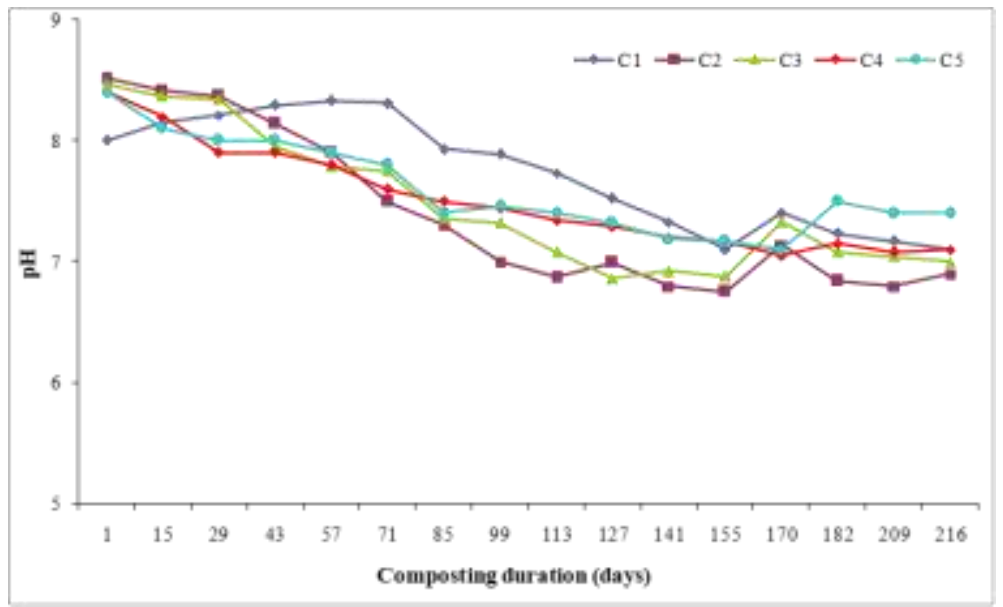

Fig. 2. Evolution of $\mathrm{pH}$ of the tested compost windrows during their composting process. 
Initial electrical conductivity (EC) values ranged from 5.51 to $8.27 \mathrm{mS} / \mathrm{cm}$ in the beginning of the experiment. EC increased during the composting process until 170 days in all windrows (Fig. 3). The highest EC value was recorded during this period and reached $8.98 \mathrm{mS} / \mathrm{cm}$ in $C_{1}, 9.34 \mathrm{mS} / \mathrm{cm}$ in $C_{2}, 9.44 \mathrm{mS} / \mathrm{cm}$ in $C_{3}, 8.36 \mathrm{mS} / \mathrm{cm}$ in $C_{4}$, and $8.84 \mathrm{mS} / \mathrm{cm}$ in $C_{5}$. However, these values dropped and reached their lowest values at the end of composting process (i.e. maturation phase) (Fig. 3). Therefore, EC values, noted after 223 days of composting, varied significantly (at $P \leq 0.05$ ) depending on tested composts where $C_{1}, C_{3}$ and $C_{5}$ showed the highest EC values with $4.47,5.22$ and $4.86 \mathrm{mS} / \mathrm{cm}$, respectively, whereas for $C_{2}$ and $C_{4}$ this parameter ranged between 3.6 and $3.9 \mathrm{mS} / \mathrm{cm}$.

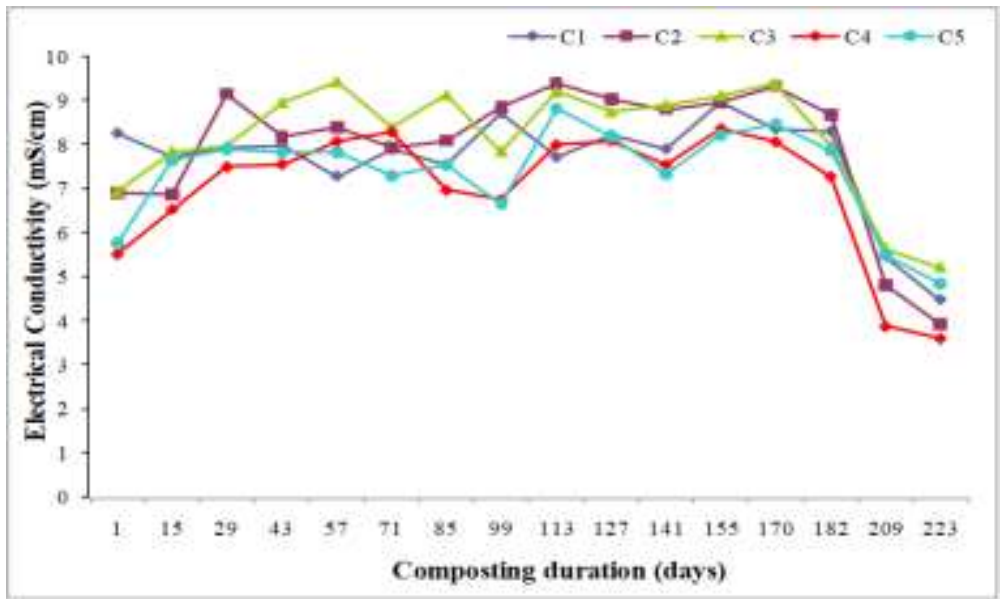

Fig. 3. Evolution of the electrical conductivity of the tested compost windrows during their composting process.

\section{Dry matter}

During the composting process, an initial slight increase in dry matter was noted within the first 15 days. The dry matter content increased and reached a maximum of $96.2-97.8 \%$ within 182 days of composting, followed by a drop to $70.13-73.87 \%$ at the end of the process where no significant (at $P \leq 0.05$ ) differences were registered between tested composts (Fig. 4).

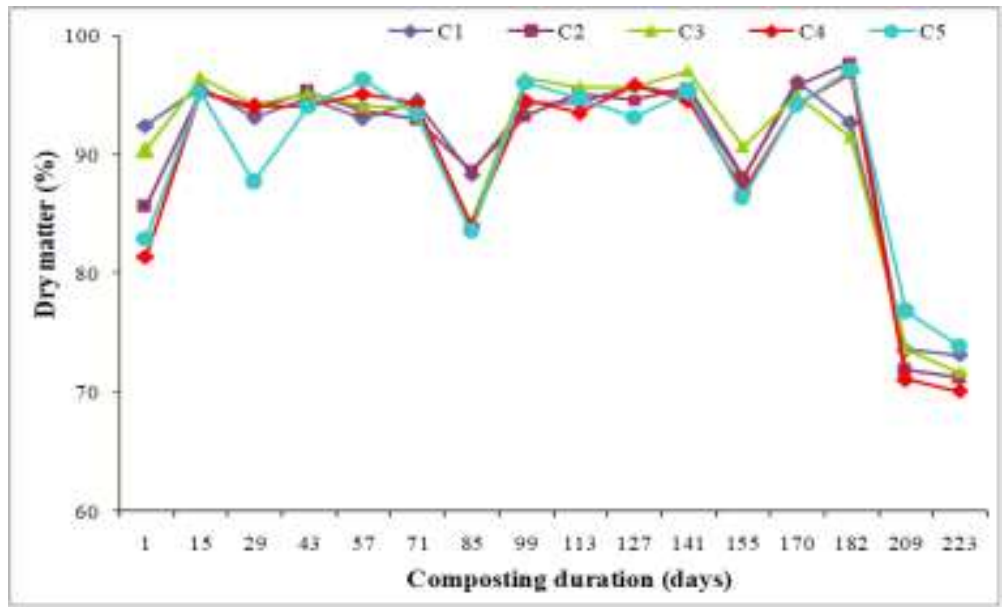

Fig. 4. Changes in the dry matter of the tested compost windrows during their composting process.

\section{Bulk density}

The results indicated that the bulk density increased from the initial $\left(0.20-0.26 \mathrm{~g} / \mathrm{cm}^{3}\right)$ to the final $\left(0.34-0.55 \mathrm{~g} / \mathrm{cm}^{3}\right) \mathrm{stages}($ Fig. 5$)$. At the end of the maturation phase, this parameter varied significantly (at $P \leq 0.05$ ) depending on the different windrows of mature composts. The highest value $\left(0.55 \mathrm{~g} / \mathrm{cm}^{3}\right)$ was recorded in composts $C_{2}, C_{4}$ and $C_{5}$. However, for $C_{1}$ and $C_{3}$, the bulk density was significantly (at $P \leq 0.05$ ) similar with an average of 0.41 and $0.34 \mathrm{~g} / \mathrm{cm}^{3}$, respectively (Fig. 5). 


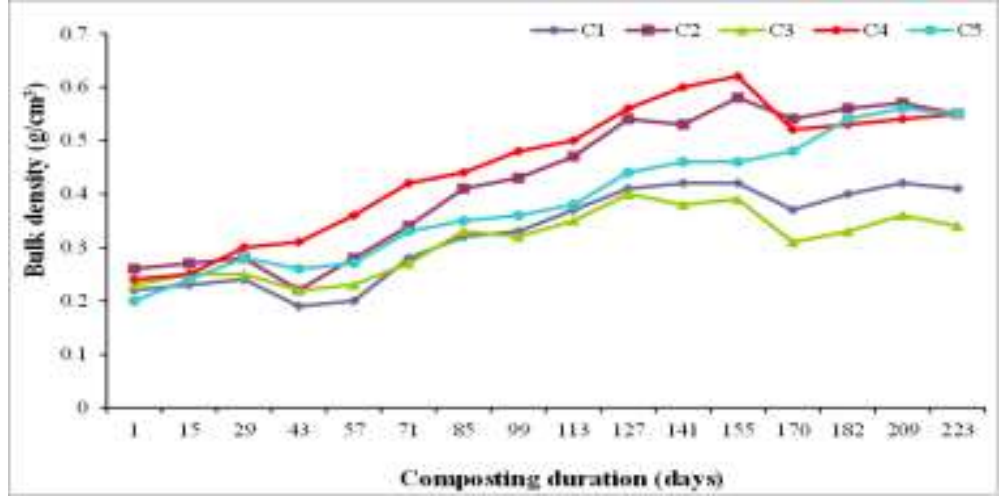

Fig. 5. Evolution of bulk density of the tested compost windrows during their composting process.

Total porosity

The total porosity of initial samples ranged between 59 and $80 \%$ for the different tested composts. Porosity decreased during composting with some peaks and reached $50.1-56.5 \%$ at the end of the process. No significant differences (at $P \leq 0.05$ ) were recorded between tested treatments (Fig. 6).

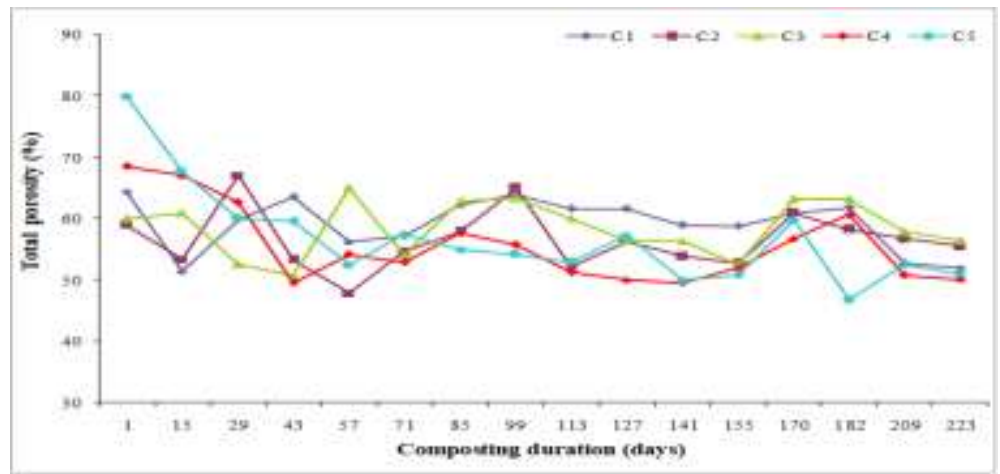

Fig. 6. Variation of the total porosity of the tested compost windrows during their composting process.

\section{Water retention}

Regarding water retention, the initial values ranged from 35.08 to $44.58 \%$ and dropped between the $29^{\text {th }}(26.6-35.9 \%)$ and the $57^{\text {th }}$ (28.3-31.8\%) day of composting. The retention water capacity slowly rose to $33-39 \%$ beyond 7 months and no significant differences (at $P \leq 0.05$ ) were detected between composted materials (Fig. 7).

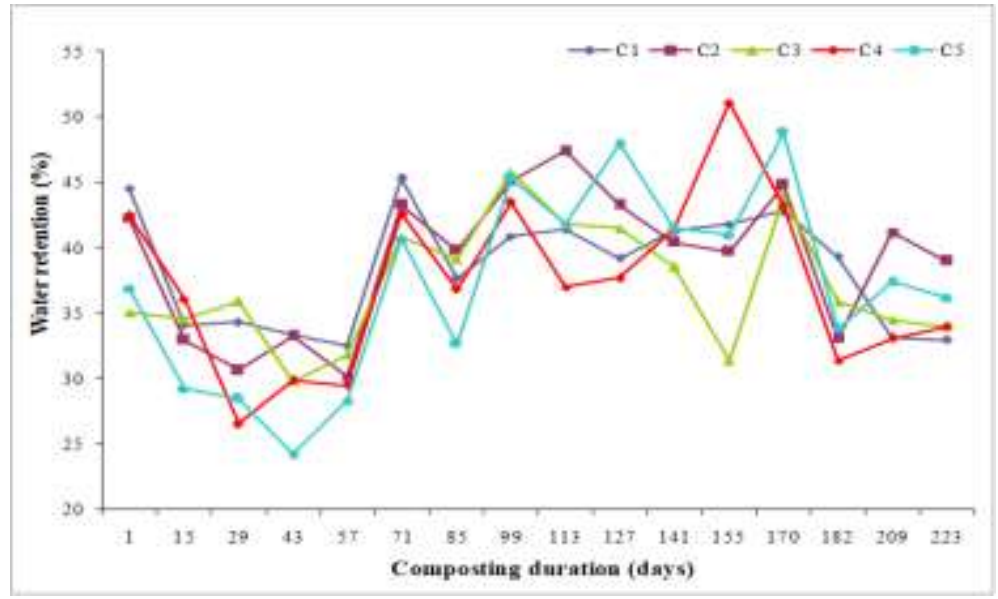

Fig. 7. Variation of the water retention of the tested compost windrows during their composting process. 


\section{Organic matter}

During composting, the organic matter content was reduced and stabilized at the end of the process. The initial values ranged from 53.7 to $66.9 \%$ and the highest values, estimated at 66.9 and $62.9 \%$, were noted on $C_{4}$ and $C_{5}$ windrows, respectively (Fig. 8 ). A loss of organic matter occurred in all compost windrows due to mineralization of organic compounds. The organic matter content decreased and stabilized especially during the maturation phase and ranged between 40.13 and $43.4 \%$ at the end of the composting process (Fig. 8). No significant differences (at $P \leq 0.05$ ) were recorded between the different mature composts regarding the organic matter content.

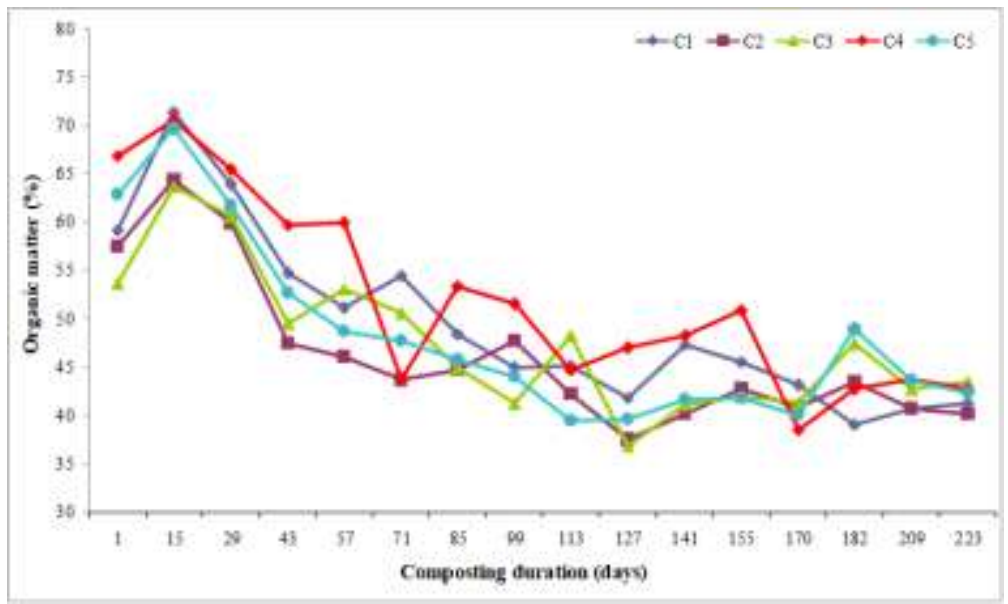

Fig. 8. Variation of the organic matter of the tested compost windrows during their composting process.

\section{Total organic carbon}

The initial total organic carbon ranged between 31.23 and $37.38 \%$ and increased to $37.05-41 \%$ for $C_{2}, C_{3}, C_{4}$ and $C_{5}$ after 15 days of composting. These values decreased and stabilized at 23.33-25.23\% at the end of the maturation phase (Fig. 9). Similar total organic carbon trends were observed in all windrows.

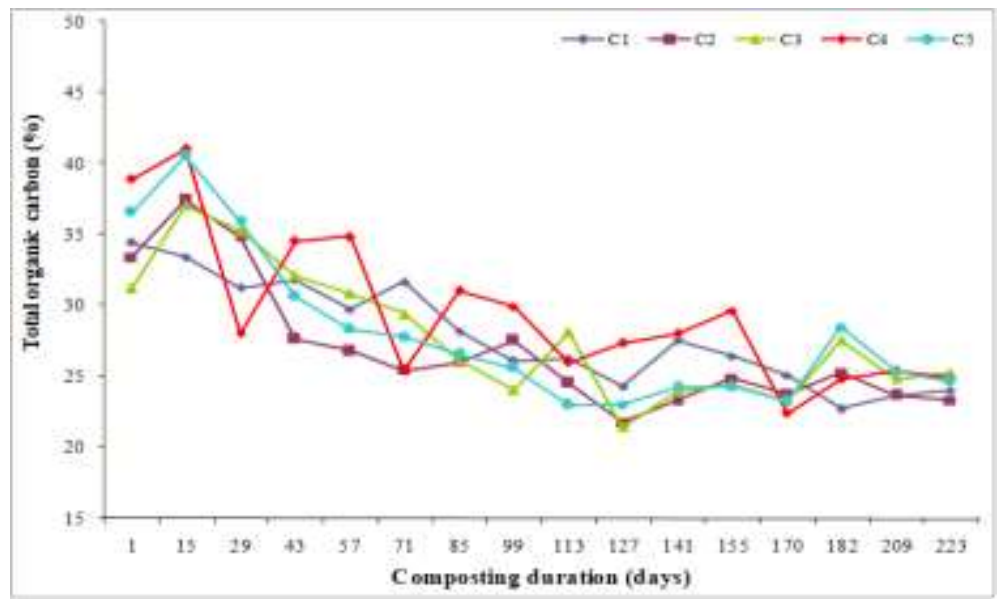

Fig. 9. Variation of the total organic carbon of the tested compost windrows during their composting process.

\section{Nitrogen content}

As for nitrogen content, a significant difference was noted between composts and sampling dates (i.e. at the beginning or at the end of the composting process) and their interactions (Table 3). In fact, at the beginning of the process, the nitrogen contents ranged from 1.32 to $1.9 \%$ for the different compost types, with the lowest values recorded in composts $C_{1}, C_{4}$ and $C_{5}$. Nevertheless, even though $\mathrm{N}$ contents decreased to 1.05 and $0.92 \%$ for composts $C_{1}$ and $C_{2}$ at the end of composting, $C_{4}$ and $C_{5}$ maintained relatively highest contents estimated at 1.82 and $1.85 \%$, respectively (Table 3 ). 
Table 3. Changes in the contents (\% dry matter) of some nutrient elements in the tested composts at the beginning and at the end of the composting process.

\begin{tabular}{|c|c|c|c|c|c|}
\hline \multirow{2}{*}{$\begin{array}{l}\text { Nutrient } \\
\text { elements }\end{array}$} & C1 & C2 & C3 & C4 & $\mathbf{C 5}$ \\
\hline & \multicolumn{5}{|l|}{ First day } \\
\hline N (\%) & $1.63 \pm 0.033 \mathrm{e}$ & $1.43 \pm 0.058 \mathrm{~d}$ & $1.32 \pm 0.166 c$ & $1.9 \pm 0.029 f$ & $1.65 \pm 0.029 \mathrm{e}$ \\
\hline $\mathbf{P}(\%)$ & $0.09 \pm 0.014 b c$ & $0.07 \pm 0.018 \mathrm{ab}$ & $0.14 \pm 0.002 \mathrm{~d}$ & $0.08 \pm 0.004 b c$ & $0.073 \pm 0.011 \mathrm{ab}$ \\
\hline K (\%) & $1.46 \pm 0.021 \mathrm{~d}$ & $1.59 \pm 0.004 \mathrm{f}$ & $1.55 \pm 0.004 \mathrm{e}$ & $1.54 \pm 0.009 \mathrm{e}$ & $1.55 \pm 0.018 \mathrm{e}$ \\
\hline Ca (\%) & $3.47 \pm 0.184 \mathrm{~d}$ & $2.7 \pm 0.044 \mathrm{a}$ & $2.96 \pm 0.071 b c$ & $3.04 \pm 0.058 c$ & $3.4 \pm 0.018 d$ \\
\hline \multirow[t]{2}{*}{$\mathrm{Na}(\%)$} & $0.46 \pm 0.011 \mathrm{c}$ & $0.55 \pm 0.002 \mathrm{~d}$ & $0.55 \pm 0.022 \mathrm{de}$ & $0.6 \pm 0.005 \mathrm{e}$ & $0.59 \pm 0.009 \mathrm{de}$ \\
\hline & \multicolumn{5}{|c|}{ End of the maturation phase } \\
\hline $\mathbf{N}(\%)$ & $1.05 \pm 0.076 b$ & $0.92 \pm 0.044 \mathrm{a}$ & $1.43 \pm 0.033 d$ & $1.82 \pm 0.014 \mathrm{f}$ & $1.85 \pm 0.029 f$ \\
\hline $\mathbf{P}(\%)$ & $0.104 \pm 0.008 c$ & $0.102 \pm 0.001 c$ & $0.05 \pm 0.0039 a$ & $0.06 \pm 0.003 a$ & $0.06 \pm 0.0062 \mathrm{ab}$ \\
\hline K (\%) & $1.32 \pm 0.014 c$ & $1.2 \pm 0.002 b$ & $1.29 \pm 0.001 c$ & $1.2 \pm 0.007 \mathrm{~b}$ & $1.15 \pm 0.007 \mathrm{a}$ \\
\hline Ca (\%) & $2.94 \pm 0.052 b c$ & $2.53 \pm 0.041 \mathrm{a}$ & $2.76 \pm 0.067 \mathrm{ab}$ & $3.39 \pm 0.049 d$ & $2.99 \pm 0.014 c$ \\
\hline $\mathrm{Na}(\%)$ & $0.41 \pm 0.03 \mathrm{ab}$ & $0.4 \pm 0.005 a$ & $0.45 \pm 0.002 b c$ & $0.44 \pm 0.002 b c$ & $0.41 \pm 0.007 \mathrm{ab}$ \\
\hline \multirow{2}{*}{ LSD } & N (\%) & $\mathbf{P}(\%)$ & $\mathrm{K}(\%)$ & Ca (\%) & $\mathrm{Na}(\%)$ \\
\hline & 0.089 & 0.022 & 0.027 & 0.128 & 0.032 \\
\hline
\end{tabular}

Values of each line followed by the same letter are not significantly different according to Duncan Multiple Range test (at $P \leq 0.05$ ).

\section{Phosphorus content}

The $\mathrm{P}$ content was significantly (at $P \leq 0.05$ ) affected by composts studied and sampling dates, i.e. at the beginning or at the end of the composting process); a significant interaction was also noted between these two factors (Table 3). At the beginning of composting, the compost $\mathrm{C}_{3}$ had high total $\mathrm{P}$ content estimated at $0.14 \%$ while the other composts had contents ranging between 0.07 and $0.09 \%$. However, at the end of the composting process, the total P content increased to 0.102 and $0.104 \%$ in composts $C_{2}$ and $C_{1}$, respectively. Nevertheless, no significant differences were noted between composts $C_{3}, C_{4}$ and $C_{5}$ (Table 3 ).

\section{Potassium content}

The potassium contents varied significantly (at $P \leq 0.05$ ) depending on tested composts as well as on the interaction between composts and sampling dates (Table 3 ). In fact, the highest initial $\mathrm{K}$ content was recorded in compost $\mathrm{C}_{2}(1.59 \%)$, whereas the lowest one was noted in compost $C_{1}(1.46 \%)$. For $C_{3}, C_{4}$ and $C_{5}, K$ concentrations were similar and were estimated at $1.54-1.55 \%$. However, the mature composts $C_{1}$ and $C_{3}$ had the highest $K$ contents with 1.32 and $1.29 \%$, respectively, followed by $C_{2}$ and $C_{4}$ with $1.2 \%$. The lowest concentration (1.15\%) was recorded in the compost $C_{5}$ (Table 3 ).

Calcium content

The calcium contents of tested composts varied significantly (at $P \leq 0.05$ ) depending on compost types (depending on raw material composition) and sampling dates. A significant interaction was also noted between both fixed factors. In fact, as indicated in Table 3 , the initial $\mathrm{Ca}$ contents were highest, $3.47 \%$ and $3.4 \%$, in composts $C_{1}$ and $C_{5}$, respectively, and lowest in $C_{2}$ (2.7\%). However, at the end of the composting process, the most important $\mathrm{Ca}$ concentration (3.39\%) was recorded in compost $\mathrm{C}_{4}$, followed by $\mathrm{C}_{1}$ and $\mathrm{C}_{5}$ (2.94 and 2.99\%, respectively). Compost $\mathrm{C}_{2}$ had the lowest Ca content which was estimated at $2.53 \%$ (Table 3 ).

\section{Sodium content}

The sodium contents varied significantly depending on tested composts and sampling dates; a significant interaction was noted between both fixed factors $(P \leq 0.05)$. The highest initial $\mathrm{Na}$ content was recorded in composts $C_{3}, C_{4}$ and $C_{5}$ with 0.55 , 0.6, and $0.59 \%$, respectively, and the lowest one was noted in compost $C_{1}(0.46 \%)$. However, in all windrows, the total Na contents decreased with the increase of composting duration and ranged between 0.4 and $0.45 \%$ (Table 3 ).

\section{Microbial characterization}

The successions of microbial populations during the different phases of composting are given in Tables 4 and 5 . In fact, during the mesophilic phase, all composts were colonized in major proportion by aerobic mesophilic bacteria $\left(3.35-111.8 \times 10^{7} \mathrm{CFU} / \mathrm{g}\right.$ of compost) and in the lower level by mesophilic fungi (0.33-2.16 × $10^{6} \mathrm{CFU} / \mathrm{g}$ of compost) (Table 4). However, the microbial community varied and decreased during the following three phases. Indeed, during the thermophilic phase, the most important counts of aerobic thermophilic bacteria were noted in compost $C_{1}$ with $1618.1 \times 10^{5} \mathrm{CFU} / \mathrm{g}$ of compost, whereas $C_{4}$ had a low bacterial number $\left(2.12 \times 10^{5} \mathrm{CFU} / \mathrm{g}\right.$ of compost) and no thermophilic fungi were detected (Table 4). 
Table 4. Bacterial counts from the tested composts during the different composting phases noted after $24 \mathrm{~h}, 48 \mathrm{~h}$ and $72 \mathrm{~h}$ of incubation in the dark.

\begin{tabular}{|c|c|c|c|c|c|c|c|c|c|c|c|c|}
\hline \multirow{3}{*}{ Compost } & \multicolumn{12}{|c|}{ Composting phase/Incubation duration } \\
\hline & \multicolumn{3}{|c|}{$\begin{array}{l}\text { Mesophilic phase } \\
\text { (107 CFU/g of compost) }\end{array}$} & \multicolumn{3}{|c|}{$\begin{array}{l}\text { Thermophilic phase } \\
\text { ( } 10^{5} \mathrm{CFU} / \mathrm{g} \text { of compost) }\end{array}$} & \multicolumn{3}{|c|}{$\begin{array}{l}\text { Cooling phase } \\
\text { ( } 10^{5} \mathrm{CFU} / \mathrm{g} \text { of compost) }\end{array}$} & \multicolumn{2}{|c|}{$\begin{array}{l}\text { Maturing phase } \\
\left(10^{5} \text { CFU/g }\right. \\
\text { compost) }\end{array}$} & \multirow{2}{*}{$\begin{array}{r}\text { of } \\
72 \mathrm{~h} \\
\end{array}$} \\
\hline & $24 \mathrm{~h}$ & $48 \mathrm{~h}$ & $72 \mathrm{~h}$ & $24 \mathrm{~h}$ & $48 \mathrm{~h}$ & $72 \mathrm{~h}$ & $24 \mathrm{~h}$ & $48 \mathrm{~h}$ & $72 \mathrm{~h}$ & $24 \mathrm{~h}$ & $48 \mathrm{~h}$ & \\
\hline$C_{1}$ & 0.40 & 1.95 & 3.35 & 1450 & 1527.2 & 1618.1 & 1.06 & 4.05 & 4.97 & 1.12 & 2.66 & 2.92 \\
\hline$C_{2}$ & 65 & 73.5 & 96.5 & 4.93 & 9.73 & 10.09 & 96 & 182.7 & 231.81 & 1.44 & 2.27 & 2.45 \\
\hline$C_{3}$ & 58.8 & 92.1 & 111.8 & 17.95 & 28.55 & 29.8 & 76.5 & 88 & 115 & 2.21 & 3.65 & 10.8 \\
\hline $\mathrm{C}_{4}$ & 3.40 & 10.05 & 20.95 & 0.77 & 1.77 & 2.12 & 59 & 89 & 96.5 & 1.18 & 2.85 & 3.92 \\
\hline$C_{5}$ & 1.15 & 2.97 & 4.15 & 0.30 & 0.98 & 5.13 & 132.5 & 167 & 177 & 0.95 & 1.39 & 1.60 \\
\hline
\end{tabular}

Once the compost cools down, aerobic mesophilic bacteria predominated and reached $10.8 \times 10^{5} \mathrm{CFU} / \mathrm{g}$ of compost for mature $\mathrm{C}_{3}$ but ranged between 1.6 and $3.92 \times 10^{5} \mathrm{CFU} / \mathrm{g}$ of compost for the other mature composts (Table 4).

Mesophilic fungi were more recovered when the temperature dropped, while their numbers increased for some composts and diminished for others (Table 5). Therefore, mature $C_{2}$ had the highest number of mesophilic fungi estimated at $11.6 \times 10^{4} \mathrm{CFU} / \mathrm{g}$ of compost, whereas these fungi were relatively less abundant in composts $C_{1}, C_{3}, C_{4}$ and $C_{5}$ with $4.0 \times 10^{4}, 4.7 \times 10^{4}, 6.6 \times 10^{4}$, and $5.260 \times 10^{4} \mathrm{CFU} / \mathrm{g}$ of compost after $72 \mathrm{~h}$ of incubation at $35^{\circ} \mathrm{C}$, respectively (Table 5 ).

Table 5 Fungal counts from the different composts during the different phases of composting after $24 \mathrm{~h}, 48 \mathrm{~h}$ and $72 \mathrm{~h}$ of incubation in the dark.

\begin{tabular}{|c|c|c|c|c|c|c|c|c|c|c|c|c|}
\hline \multirow{3}{*}{ Compost } & \multicolumn{12}{|c|}{ Composting phase/Incubation duration } \\
\hline & \multicolumn{3}{|c|}{$\begin{array}{l}\text { Mesophilic phase } \\
\text { (106 CFU/g of compost) }\end{array}$} & \multicolumn{3}{|c|}{$\begin{array}{l}\text { Thermophilic phase } \\
\text { (CFU/g of compost) }\end{array}$} & \multicolumn{3}{|c|}{$\begin{array}{l}\text { Cooling phase } \\
\text { (104 CFU/g of compost) }\end{array}$} & \multicolumn{3}{|c|}{$\begin{array}{l}\text { Maturation phase } \\
\left(10^{4} \mathrm{CFU} / \mathrm{g} \text { of compost) }\right.\end{array}$} \\
\hline & $24 \mathrm{~h}$ & $48 \mathrm{~h}$ & $72 \mathrm{~h}$ & $24 \mathrm{~h}$ & $48 \mathrm{~h}$ & $72 \mathrm{~h}$ & $24 \mathrm{~h}$ & $48 \mathrm{~h}$ & $72 \mathrm{~h}$ & $24 \mathrm{~h}$ & $48 \mathrm{~h}$ & $72 \mathrm{~h}$ \\
\hline $\mathrm{C}_{1}$ & 0.06 & 0.14 & 0.33 & 0 & 0 & 0 & 3.7 & 4.5 & 5.0 & 3.6 & 3.7 & 4.0 \\
\hline$C_{2}$ & 0.10 & 0.16 & 0.18 & 0 & 0 & 0 & 3.6 & 5.5 & 7.1 & 3.5 & 9.6 & 11.6 \\
\hline$C_{3}$ & 1.99 & 2.14 & 2.16 & 0 & 0 & 0 & 3.6 & 20.0 & 36.1 & 2.7 & 4.7 & 4.7 \\
\hline
\end{tabular}

Compost was 10-fold diluted (10-2-10-10) and $100 \mu$ l of each dilution spread on PDA medium for fungi and on PCA medium for bacteria. Incubation temperatures were $35^{\circ} \mathrm{C}$ for mesophiles and $60^{\circ} \mathrm{C}$ for thermophiles.

\section{Phytotoxicity test}

The toxicity responses of barley seeds to the five tested composts, during the composting period, was expressed by the relative seed germination as illustrated in Fig. 10. At the $30^{\text {th }}$ and $80^{\text {th }}$ days after the beginning of the composting process, the germination of barley seeds was very low with initial values estimated at $0.2-13.2 \%$ and $8.1-19.7 \%$, respectively. At the $125^{\text {th }}$ day, the germination values ranged between 21 and $27.3 \%$ for all studied composts. However, at the $220^{\text {th }}$ day, barley seeds germinated at more than $63 \%$ (63.2-81.3\%) following their treatments with the different composts (Fig. 10).

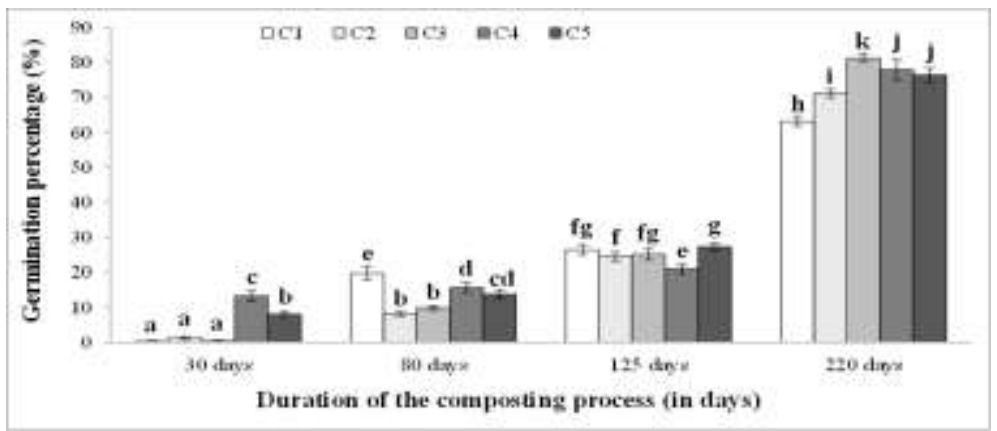

Figure 10 Evolution of the germination (in \%) of barley seeds following their treatment with the tested composts at different phases during their composting process.

Notes: Bars sharing the same letter are not significantly different according to Duncan Multiple Range test (at $P \leq 0.05$ ); LSD (Composts $\times$ Sampling dates $)=1.73 \%$ at $P \leq 0.05$. 


\section{Discussion}

Composting is a process of solid waste management to convert different organic matter sources into useful humus substance to enhance the physical and nutritional quality of soil (Pan and Sen, 2013). In order to produce a compost with a good quality, studies were conducted for eight months to investigate the physico-chemical changes during the composting of various organic materials with different proportions (cow manure, chicken manure, sheep manure, olive mill solid waste, green waste) under local conditions.

In the current study, the temperature profiles of all the composted materials followed the familiar pattern observed during composting and indicated the biochemical activities of composts (Chowdhury et al. 2014; Ryckeboer et al., 2003). An initial fast increase to thermophilic temperatures above $50^{\circ} \mathrm{C}$ was recorded after 2 days and reached $60.07-67^{\circ} \mathrm{C}$ after 7 to 22 days. $\mathrm{C} 4$ and C5 had the longest duration of the thermophilic phase, occurring from the 7th to the 52th day, with the highest peaks of 61.29 and $64.59^{\circ} \mathrm{C}$, respectively, recorded after 21 days. However, the highest temperature was recorded at the 20th day in windrow $\mathrm{C} 1$ $\left(63.33^{\circ} \mathrm{C}\right)$, at the 23 th day in $\mathrm{C} 2\left(60.1^{\circ} \mathrm{C}\right)$, and at the 7 th day in $\mathrm{C} 3\left(67^{\circ} \mathrm{C}\right)$. All windrows remained above $45^{\circ} \mathrm{C}$ for about approximately 4-5 months. Then, the temperatures slowly declined and decreased to ambient levels by the final stage of composting i.e. after about 8 months. Therefore, the composting process could be divided into four phases: (i) a first mesophilic phase which lasted for two days; (ii) a thermophilic phase $\left(60.07-67^{\circ} \mathrm{C}\right)$, lasting approximately $4-5$ months; (iii) a second mesophilic phase during which all compost windrows declined below $45^{\circ} \mathrm{C}$; and (iv) a maturation and stabilization phase after about 8 months. Similar trends were observed in different industrial-scale compost windrows using various organic materials (Chowdhury et al., 2014; Gigliotti et al., 2012; Michailides et al., 2014). However, the duration of the process mainly depends upon the structural composition of initial biomass (i.e., lignin, cellulose and hemicellulose contents) subjected to composting and the operating and environmental conditions of the composting location (Diaz et al., 2002).

Temperature profiles are the most significant indicators of the microbiological activity in the composting windrows (Cáceres et al., 2015). Different microbial populations predominate during the composting phases (Ryckeboer et al., 2003). In the current investigation, during mesophilic phase, all composts were colonized in major proportion by mesophilic bacteria and to lower extent by mesophilic fungi. Mesophilic microorganisms are known to be the dominant active degraders of fresh organic waste materials (Ryckeboer et al., 2003). Nevertheless, the microbial community decreased during the following three phases. During the thermophilic phase, the increase of temperature involves a rapid transition from mesophilic to thermophilic microflora (Corominas et al., 1987; Falcon et al., 1987; Ryckeboer et al., 2003). In the present study, thermophilic bacteria were isolated from tested composts with different numbers, whereas no thermophilic fungi were recorded. This may be explained by the ability of some bacteria to produce thick-walled endospores which are resistant to heat, radiation and chemical disinfection (Haug, 1993). Moreover, high temperatures support the degradation of recalcitrant organics such as lignocellulose and elimination of pathogenic and allergenic microorganisms. Bacteria compete with other organisms for nutrients and can inhibit microbial growth due to the production of antibiotics, lytic enzymes or even by parasitism (Ryckeboer et al., 2003). Furthermore, according to Dix and Webster (1995), the majority of fungi are mesophilic microbes which grow between 5 and $37^{\circ} \mathrm{C}$.

During the cooling phase, mesophilic bacteria predominated and reached 1.6 $\times 105-10.8 \times 105 \mathrm{UFC} / \mathrm{g}$ of compost at the end of the process, but mesophilic fungi are present with a fewer numbers $(4.0 \times 104-11.6 \times 104 \mathrm{CFU} / \mathrm{g}$ of mature compost). The interaction between various functional microorganism groups depends on nutrient resources and the biochemical mechanisms of transformation changes of organic and inorganic matter (Insam et al., 2002). Microorganisms with high hydrolyzing activities existed, they are spore forming (Bacillus sp.), mycelial (Actinomyces and fungi) and cellulolytic (mainly fungi) agents. The bacteria Azotobacter, Pseudomonas, Azospirillum use simple organic material formed at hydrolysis and fermentation in aerobic conditions. The population redistribution to a degree of dominant and the development of stable forms of microorganisms preserve the diversity of species in the structure of community and signify structural-functional changes (Rebollido et al., 2008).

Therefore, the microbial activities act directly on the organic matter decomposition of compost depending on the materials used. In fact, bacteria lead early on the composting stage, while fungi are present during the process but are highly active when water levels are below $35 \%$ and inactive at temperatures over $60^{\circ} \mathrm{C}$ (Bernal et al., 2009). During the maturation phase, Actinomycetes sp. predominate, and with fungi, are capable of degrading highly resistant polymers (Agnolucci et al. 2013). According to Haug (1993), easily degradable organic compounds, such as simple carbohydrates, amino acids and fats, are degraded rapidly at the beginning of the composting process while more resistant organic substrates such as cellulose, hemicellulose and lignin are partially degraded and transformed slowly. Thus, the organic matter content of composts decreased and stabilized during the maturation phase with ranges of 40.13 to $43.4 \%$ statically similar at the end of the process. These results are in agreement with those of Benito et al. (2005) who noted that the highest total organic matter value is around $44 \%$. However, it was reported that high quality composts should have a minimum of $50 \%$ organic matter content (Fuchs et al., 2001) but Larbi (2006) showed that for old composts, organic content is only $17 \%$.

The degradation of organic matter decreases progressively as the composting process advances, because of the reduction of available carbon sources and the formation of new complex substances, and the humification process that predominates over 
mineralization during the maturation phase (Gigliotti et al., 2012). Indeed, compost stability could be expressed as a function of the degradation of total organic carbon and this parameter could be helpful in the monitoring of the composting process and in the evaluation of compost quality (Cooperband et al., 2003). In fact, the initial total organic carbon range was 31.23-37.38\%. The values decreased and stabilized at about $23.33-25.23 \%$ at the end of the maturation phase. These results are in agreement with those of Chowdhury et al. (2013) and El-Sayed (2015) who found that the total organic carbon value may be higher than $16 \%$.

During the composting process, the $\mathrm{pH}$ of the different compost windrows dropped from 8-8.51 to 6.83-7.37, which may be due to the mineralization and ammonification of organic matter by the activities of microorganisms favoring a near-neutral pH (Wong et al., 2005). According to Huang et al. (2001), the decrease in $\mathrm{pH}$ may be due to the volatilization loss of ammonia and the increase in $\mathrm{H}+$ from the nitrification process. Moreover, Mustin (1987) found that the microbial decomposition of organic matter and the production of organic and inorganic acids would be responsible for the $\mathrm{pH}$ decrease. Similar results were reported in other studies (Michailides et al., 2011). These pH values may benefit microbial activities by creating favorable environmental conditions and are compatible with most cultivated crops (Chowdhury et al., 2014; Lasaridi et al., 2006).

For all the studied composts, there was an increase in electrical conductivity $(E C)$ as the composting process progressed. These results confirmed those of Mupondi et al. (2006) and Jagadabhi et al. (2019). EC of all the compost materials increased from 5.51$8.27 \mathrm{mS} / \mathrm{cm}$ to $8.36-9.34 \mathrm{mS} / \mathrm{cm}$ after 170 days. This is due to the fact that as the process progressed, the concentration of soluble mineral salts increased, contributing to higher EC, which reflected the progressive mineralization of the organic matter into soluble forms (Cáceres et al., 2013). High EC values of composts can be attributed to the salinity of the raw materials (cow, chicken and sheep manures) used in the experiment. However, EC suddenly dropped and reached the lowest values at the end of composting as demonstrated for $\mathrm{C} 2$ and $\mathrm{C} 4$ ( 3.9 and $3.6 \mathrm{mS} / \mathrm{cm}$, respectively). This reduction is caused by salt leaching with successive watering. Therefore, in this study, the EC values of the mature composts were near the Greek standard and the Association of Swiss compost plants directive limits of $4 \mathrm{mS} / \mathrm{cm}$ (Fuchs et al., 2001; Lasaridi et al., 2006). Thus, this compost is probably suitable for application on a variety of agricultural crops.

Parameters such as dry matter content and bulk density had been shown to characterize the compactness and strength of manure substrates (Saint-Joly et al., 1989). In fact, an increase in dry matter was observed and followed by a drop to 70.13-73.87\%. Composts lose a lot of water and dry up during the thermophilic stage of the composting process (Mustin, 1987; Venglovsky et al., 2005). Several previous researches showed that some composting processes should operate with moisture contents in the 40$60 \%$ band (Stentiford, 1996). Sullivan and Costello (2010) reported that matured composts should be in the moisture content range of $35-60 \%$, but it was shown that good mature compost should have moisture content less than $50 \%$ (Fuchs et al., 2001). Therefore, the difference in the optimal moisture content between materials depends on the particle size of the materials and their physical structure (Forshell, 1993). On the whole, fluctuations in dry matter content may have been caused by natural variation.

The present results indicate that the bulk density increased from $0.20-0.26 \mathrm{~g} / \mathrm{cm} 3$ (initial state) to $0.34-0.55 \mathrm{~g} / \mathrm{cm} 3$ (final state) and varied significantly depending on tested windrows of mature composts. Larney et al. (2000) studied a straw and cattle manure mix and noted a 3-4 fold increase in bulk density over the thermophilic and maturation phases. These findings are in accordance with those of Huerta-Pujol et al. (2010) and El-Sayed (2015) who noted similar values of mature composts.

The composts tested in the current study varied in their total porosity and water retention capacity, but the difference was not statistically significant at the end of the composting process. In fact, porosity and water retention decreased during composting with some peaks and reached 50.1-56.5 and 33-39\%, respectively. However, Gruda and Schnitzler (2004) reported that an optimal growing medium must have a total porosity of more than $85 \%$. Air filled porosity of the unsaturated organic matrix influences the heat and mass transport processes and thus microbial kinetics (Haug, 1993). Moreover, water retention is an important property of horticultural substrates and different researchers reported it differently (Wilson, 1984). Nevertheless, Nkongolo and Caron (1999) considered water retention and air-filled porosity insufficient to describe the growing medium properties, characteristics of gas exchanges.

The total $\mathrm{N}, \mathrm{P}$ and $\mathrm{K}$ contents are dependent upon the compost composition and the composting time. In fact, the total $\mathrm{N}$ contents, obtained in the present study ranged from 1.32 to $1.9 \%$ for the different compost types at the beginning of the process and from 0.82 to $1.85 \%$ at the end. They increased for some composts (C3 and C5), decreased for others (C1 and C2) and maintained stability for $\mathrm{C} 4$. The increase in $\mathrm{N}$ content can be attributed to the loss of dry matter (as carbon) in the form of $\mathrm{CO} 2$ and water vapor loss during microbial decomposition and natural evaporation and processes. Several other studies reported similar results for $\mathrm{N}$ contents (Jagadabhi et al., 2019). However, the reduction of the $\mathrm{N}$ content could be due to the assimilation processes carried out by the utilization of inorganic nitrogen by microorganisms and the conversion of nitrogen into proteins, the mineralization and the volatilization (Cáceres et al., 2006; Pan and Sen, 2013). The composts C4 and C5, containing cow manure (70\%), sheep manure (25\%) and olive-mill solid waste or green waste (5\%), had the highest N concentrations after 223 days of composting. 
The $\mathrm{P}$ content was significantly affected by composts and composting duration. Despite no significant variation in phosphorus values were recorded in $\mathrm{C} 1, \mathrm{C} 4$ and $\mathrm{C} 5$, an important decrease in the $\mathrm{P}$ concentration was noted in $\mathrm{C} 3$ and an increase was observed in $\mathrm{C} 2$. The mature composts $\mathrm{C} 1$ and $\mathrm{C} 2$, with $5 \%$ of olive mill solid waste, had the highest $\mathrm{P}$ contents, followed by the other three composts. However, these concentrations are less than those reported in other studies (Chowdhury et al., 2013; El-Sayed, 2015). Other elements such as $\mathrm{K}, \mathrm{Ca}$ and $\mathrm{Na}$ in some composts were found in low concentrations with time indicating active decomposition of the organic materials. In fact, $\mathrm{K}, \mathrm{Na}$, Ca concentrations of mature composts were 1.15-1.32, 0.4-0.45, and 2.53$3.39 \%$, respectively. Potassium and sodium are found to be particularly high in all composts in comparison to some research findings (Dix and Webster, 1995), while they are less in others (Fernández-Hernández et al., 2014). However, Ca contents were found to be within limits for composts, according to Pane et al. (2015).

In this study, the barley seed germination test, one of the most important compost maturity indicators, was used to assess any changes in compost phytotoxicity at the different composting phases. Results obtained clearly demonstrated that as composting proceeded, the germination percentage increased from $0.2-13.2 \%$ at the 30 th day to $63.2-81.3 \%$ at the end of the process. Previous research studies showed that a germination percentage above $80 \%$ indicated maturity of the compost and the absence of phytotoxicity (Bernal et al., 2009; Huang et al. 2006; Lasaridi et al. 2006; Tiquia 2005; Zucconi et al. 1985 ). Moreover, Zucconi et al. (1985) reported that a germination index below 50\% characterized immature compost and a value above $60 \%$ indicated an appropriate reduction in compost phytotoxicity. Therefore, a clear decreasing trend in phytotoxicity was noted in all compost types during the composting process. These results confirmed those of Zucconi et al. (1985) and Gigliotti et al. (2012). Some studies reported that the lack of oxygen due to high microbial activity, the accumulation of other toxic compounds such as alcohols, phenolic and volatile fatty acids, ammonia and toxic nitrogen compounds, the immobilization of nitrogen with high C:N ratios, and the presence of heavy metals and mineral salts were detrimental to seed germination (Kirchmann and Widen, 1994; Said-Pullicino and Gigliotti, 2007). Therefore, results indicated that the mature composts of the present study could be applied as an organic soil amendment.

\section{Conclusion}

The present research used parallel composting experiments to study the effect of compost duration on the quality of the final product. Physico-chemical and microbiological parameters of five composts obtained from different solid raw materials indicated a good decomposition pattern expressed by a decrease in $\mathrm{pH}$, electrical conductivity, dry matter, porosity and water retention, and microbial activities acting directly on organic matter and total organic carbon degradation. Elemental analyzes showed variation in the composition of macro- ( $\mathrm{N}, \mathrm{P}$ and $\mathrm{K}$ ) and micronutrients ( $\mathrm{Ca}$ and $\mathrm{Na}$ ), describing overall the composted materials. In addition to physico-chemical parameters, maturity can also be measured in terms of germination percentage which is based on phytotoxicity tests. A clear decreasing trend in phytotoxicity was noted in all compost types with a germination index of 63.2$81.3 \%$ at the end of the composting process. Therefore, the composting of organic solid materials was shown to be an effective method for producing end-products that are sanitized and stabilized, ensuring their benefit for agriculture. However, the compost must be of high quality to guarantee its marketability. Thus, the trial can be performed another time in order to confirm the results. Future applicative experiments will be useful to get more knowledge about compost performances on plant growth and their suppressive effect against soilborne diseases.

Conflicts of Interest: The authors declare that there are no conflicts of interest associated with this study.

\section{References}

[1] Agnew, J.M. \& Leonard, J.J. (2003). The physical properties of compost, Compost Science and Utilisation, 11(3), $238-264$. https://doi.org/10.1080/1065657X.2003.10702132

[2] Agnolucci, M., Cristani, C., Battini, F., Palla, M., Cardelli, R., Saviozzi, A. \& Nuti, M. (2013). Microbially-enhanced composting of olive mill solid waste (wet husk): bacterial and fungal community dynamics at industrial pilot and farm level, Bioresource Technology, 134, 10-16. https://doi.org/10.1016/j.biortech.2013.02.022

[3] Benito, M., Masaguer, A., De Antonio, R. \& Moliner, A. (2005). Use of pruning waste compost as a component in soilless growing media, Bioresource Technology, 96, 597-603. https://doi.org/10.1016/j.biortech.2004.06.006

[4] Bernal, M.P., Alburquerque, J.A. \& Moral, R. (2009). Composting of animal manures and chemical criteria for compost maturity assessment: A review, Bioresource Technology, 100, 5444-5453. https://doi.org/10.1016/j.biortech.2008.11.027

[5] Bi, L., Zhang, B., Liu, G., Li, Z., Liu, Y., Ye, C., Yu, X., Lai, T., Zhang, J., Yin, J. \& Liang, Y. (2009). Long-term effects of organic amendments on the rice yields for double rice cropping systems in subtropical China, Agriculture, Ecosystems and Environment, 129(4), $534-541$. https://doi.org/10.1016/j.agee.2008.11.007

[6] Bremner, J.M. \& Mulvaney, C.S. (1982). Nitrogen total, in Miller, RH and Keeney, DR (Eds.), Methods of soil analysis, Part II, American Society of Agronomers, Madison, USA, 371-378.

[7] Cáceres, R., Flotats, X. \& Marfa, O. (2006). Changes in the chemical and physicochemical properties of the solid fraction of cattle slurry during composting using different aeration strategies, Waste Management, 26(10), 1081-1091. https://doi.org/10.1016/j.wasman.2005.06.013 
[8] Cáceres, R., Narcís, C., Krystyna, M. \& Oriol, M. (2015). Evolution of process control parameters during extended co-composting of green waste and solid fraction of cattle slurry to obtain growing media, Bioresource Technology, 179, 398-406. https://doi.org/10.1016/j.biortech.2014.12.051

[9] Celano, G., Alluvione, F., Abdel Aziz, M. \& Spaccini R. (2012). The carbon dynamics in the experimental plots. Use of 13C-and 15N-labelled compounds for the soil-plant balance in carbon sequestration, in Piccolo, A (Eds.), Carbon Sequestration in Agricultural Soils. A Multidisciplinary Approach to Innovative Methods, Springer, Düsseldorf, 107-144.

[10] Chowdhury, A.K.M.M.B., Akratos, C.S., Vayenas, D.V. \& Pavlou, S. (2013). Olive mill waste composting: a review, International Biodeterioration and Biodegradation, 85, 108-119. https://doi.org/10.1016/j.ibiod.2013.06.019

[11] Chowdhury, A.K.M.M.B., Michailides, M.K., Akratos, C.S., Tekerlekopoulou, A.G., Pavlou, S. \& Vayenas, D.V. (2014). Composting of three phase olive mill solid waste using different bulking agents, International Biodeterioration and Biodegradation, 91, 66-73. https://doi.org/10.1016/j.ibiod.2014.03.012

[12] Cooperband, L.R., Stone, A.G., Fryda, M.R. \& Ravet, J.L. (2003). Relating compost measures of stability and maturity to plant growth, Compost Science and Utilization, 11(2), 113-124. https://doi.org/10.1080/1065657X.2003.10702118

[13] Corominas, E., Perestelo, F., Perez, M.L. \& Falcon, M.A. (1987). Microorgansims and environmental factors in composting of agricultural waste of the Canary Islands, in De Bertoldi, M, Ferranti, MP, L'Hermite, P and Zucconi, F (Eds.), Compost: Production, quality and use, Elsevier Applied Science, London, 127-138.

[14] Creswell, R. \& Martin, F.W. (1998). Dryland farming: Crops and techniques for arid regions. Echo Technical Note. Echo Staff North Fort Myers, FL, USA.

[15] Diaz, L.F., Savage, G.M. \& Golueke, C.G. (2002). Composting of municipal solid wastes, in Tchobanoglous, G and Kreith F (Eds.), Handbook of solid waste management, McGraw-Hill Inc., New York, 121-127.

[16] Dix, N.J. \& Webster, J. (1995). Fungal Ecology. Chapman \& Hall, Cambridge, Great Britain.

[17] El-Sayed, G.K. (2015). Some physical and chemical properties of compost, International Journal of Waste Resources, 5(1), 172. https://doi.org/10.4172/2252-5211.1000172

[18] Falcon, M.A., Corominas, E., Perez, M.L. \& Perestelo, F. (1987). Aerobic bacterial populations and environmental factors involved in the composting of agricultural and forest wastes of the Canary Islands, Biological Wastes, 20(2), 89-99. https://doi.org/10.1016/02697483(87)90159-5

[19] Fernández-Hernández, A., Roig, A., Serramiá, N., Civantos, C.G.O. \& Sánchez-Monedero, M.A. (2014). Application of compost of two-phase olive mill waste on olive grove: Effects on soil, olive fruit and olive oil quality, Waste Management, 34(7), 1139-1147. https://doi.org/10.1016/j.wasman.2014.03.027

[20] Forshell, L.P. (1993). Composting of cattle and pig manure, Journal of Veterinary Medicine B, 40(1-10), 634-640. https://doi.org/10.1111/j.1439-0450.1993.tb00186.x

[21] Fuchs, J., Schleiss, U.K. \& Wellinger, A. (2001). Caractéristiques de qualité des composts et de digestats provenant du traitement des déchets organiques [Quality characteristics of composts and digestates from organic waste treatment]. Directive of the Association of Swiss Compost Plants (ASCP).

[22] Gigliotti, G., Proietti, P., Said-Pullicino, D., Nasini, L., Pezzolla, D., Rosati, L. \& Porceddu, P.R. (2012). Co-composting of olive husks with high moisture contents: organic matter dynamics and compost quality, International Biodeterioration and Biodegradation, 67, 8-14. https://doi.org/10.1016/j.ibiod.2011.11.009.

[23] Goyal, S., Dhull, S.K. \& Kapoor, K.K. (2005). Chemical and biological changes during composting of different organic wastes and assessment of compost maturity, Bioresource Technology, 96, 1584-1591. https://doi.org/10.1016/j.biortech.2004.12.012.

[24] Gruda, N. \& Schnitzler, W.H. (2004). Suitability of wood fiber substrate for production of vegetable transplants. I. Physical properties of wood fiber substrates, Scientia Horticulturae, 100(1-4), 309-322. https://doi.org/10.1016/j.scienta.2003.10.001.

[25] Hamrouni, H. (2014). Status, priorities and needs for sustainable soil management in Tunisia, in Proceeding of the Near East and North Africa (NENA) Soil Partnership Conference. 17 - 19 June 2014. Amman, Jordan, 17-18.

[26] Haug, R.T. (1993). The practical handbook of compost engineering. Lewis Publishers, Boca Raton, USA.

[27] Huang, G.F., Fang, M., Wu, Q.T., Zhou, L.X., Liao, X.D. \& Wong, J.W.C. (2001). Co-composting of pig manure with leaves, Environmental Technology, 22(10), 1203-1212. https://doi.org/10.1080/09593332208618207.

[28] Huang, G.F., Wu, Q.T., Wong, J.W.C. \& Nagar, B.B. (2006). Transformation of organic matter during co-composting of pig manure with sawdust, Bioresource Technology, 97, 1834-1842. https://doi.org/10.1016/j.biortech.2005.08.024.

[29] Huerta-Pujol, O., Soliva, M., Martinez-Farre, F.X., Valero, J. \& Lopez M. (2010). Bulk density determination as a simple and complementary too in composting process control, Bioresource Technology, 101, 995-1001. https://doi.org/10.1016/j.biortech.2009.08.096

[30] Jagadabhi, P.S., Wani, S.P., Kaushal, M., Patil, M., Vemula, A.K. \& Rathore, A. (2019). Physico-chemical, microbial and phytotoxicity evaluation of composts from sorghum, finger millet and soybean straws, International Journal of Recycling of Organic waste in Agriculture, 8, 279-293. https://doi.org/10.1007/s40093-018-0240-8

[31] Jouraiphy, A., Amir, S., El Gharous, M., Revel, J.C. \& Hafidi M. (2005). Chemical and spectroscopic analysis of organic matter transformation during composting of sewage sludge and green plant waste, International Biodeterioration and Biodegradation, 56(2), $101-108$. https://doi.org/10.1016/j.ibiod.2005.06.002

[32] Kirchmann, H. \& Widen, P. (1994). Separately collected organic household wastes, Swedish Journal of Agricultural Research, $24(1), 3-12$.

[33] Kong, X.B., Zhang, F.R., Wei, Q., Xu, Y. \& Hui J.G. (2006). Influence of land use change on soil nutrients in an intensive agricultural region of North China, Soil and Tillage Research, 88(1-2), 85-94. https://doi.org/10.1016/j.still.2005.04.010

[34] Lal, R. (2000). Soil management in the developing countries, Soil Science, 165(1), 57-72. https://doi.org/10.1097/00010694-200001000-00008

[35] Larbi, M. (2006). Influence de la qualité des composts et de leurs extraits sur la protection des plantes contre les maladies fongiques [Influence of the quality of composts and their extracts on the control of plants against fungal diseases]. Unpublished PhD thesis, Neuchâtel, Switzerland. 
[36] Larney, F.J., Olson, A.F., Carcamo, A.A. \& Chang, C. (2000). Physical changes during active and passive composting of beef feedlot manure in winter and summer, Bioresource Technology, 75, 139-148. https://doi.org/10.1016/S0960-8524(00)00040-7

[37] Lasaridi, K., Protopapa, I., Kotsou, M., Pilidis, G., Manios, T. \& Kyriacou A. (2006). Quality assessment of composts in the Greek market: the need for standards and quality assurance, Journal of Environmental Management, 80(1), 58-65. https://doi.org/10.1016/j.jenvman.2005.08.011

[38] Liguori, L., Pane, C., Albanese, D., Celano, G., Zaccardelli, M. \& Di Matteo M. (2015). Compost and compost tea management of mini watermelon cultivations affects the chemical, physical and sensory assessment of the fruits, Agricultural Sciences, 6(1), 117-125. https://doi.org/10.4236/as.2015.61009

[39] Maniadakis, K., Lasaridi, K., Manios, Y., Kyriacou, M. \& Manios, T. (2004). Integrated waste management through producers and consumers education: composting of vegetable crop residues for reuse in cultivation, Journal of Environmental Science and Health B, 39(1), 169-183. https://doi.org/10.1081/PFC-120027447

[40] Martin-Prével, P., Gonard, J. \& Gautier, P. (1984). Méthodes analytique de référence. In : L'analyse végétale dans le contrôle de l'alimentation des plantes tempérées et tropicales [Plant analysis in nutrition control of temperate and tropical plants], Edition Lavoisier TEC \& DOC, Paris, France.

[41] Mekki, A., Dhouib, A. \& Sayadi, S. (2006). Changes in microbial and soil properties following amendment with treated and untreated olive mill waste water, Microbiological Research, 161(2), 93-101. https://doi.org/10.1016/j.micres.2005.06.001

[42] Mhindu, R.L., Menas, W. \& Esther, N. (2013). Composting of selected organic wastes from peri-urban areas of Harare, Zimbabwe, International Journal of Recycling of Organic waste in Agriculture, 2, 14-25. https://doi.org/10.1186/2251-7715-2-14

[43] Michailides, M., Christou, G., Akratos, C.S., Tekerlekopoulou, A.G. \& Vayenas, D.V. (2011). Composting of olive leaves and pomace from a three-phase olive mill plant, International Biodeterioration and Biodegradation, 65(3), 560-564. https://doi.org/10.1016/j.ibiod.2011.02.007

[44] Mupondi, L.T., Mnkeni, P.N.S. \& Brutsch, M.O. (2006). The effects of goat manure, sewage sludge and effective microorganisms on the composting of pine bark, Compost Science and Utilization, 14(3), 201-210. https://doi.org/10.1080/1065657X.2006.10702284

[45] Murphy, J. \& Riley, J.P. (1962). A modified single solution method for the determination of phosphate in natural waters, Analytica Chimica Acta, 27, 31-36. https://doi.org/10.1080/10.1016/S0003-2670(00)88444-5

[46] Muthoni, J. \& Kabira, J.N. (2010). Effects of crop rotation on soil macronutrient content and pH in potato producing areas in Kenya: Case study of KARI Tigoni station, Journal of Soil Science and Environmental Management, 1(9), 227-233. https://doi.org/10.5897/JSSEM.9000032

[47] Mustin, M. (1987). Le compost: gestion de la matière organique [Compost: management of organic matter], ed. F. Dubusc, Paris, France.

[48] Nelson, D.W. \& Sommers, L.E. (1982). Total carbon, organic carbon and organic matter, in Page, AL, Miller, RH and Keeney, DR (Eds.), Methods of soil analysis Part II, Madison, USA, 539-579.

[49] Nkongolo, N.V. \& Caron, J. (1999). Bark particle sizes and the modification of the physical properties of peat substrates, Canadian Journal of Soil Science, 79(1), 111-116. https://doi.org/10.4141/S96-084

[50] Pan, I. \& Sen, S.K. (2013). Microbial and physico-chemical analysis of composting process of wheat straw, Indian Journal of Biotechnlology, $12,120-128$.

[51] Pane, C., Villecco, D. \& Zaccardelli, M. (2013a). Short-time response of microbial communities to waste compost amendment of an intensive cultivated soil in southern Italy, Communications in Soil Science and Plant Analysis, 44(15), 2344-2352. https://doi.org/10.1080/00103624.2013.803566

[52] Pane, C., Piccolo, A., Spaccini, R., Celano, G., Villecco, D. \& Zaccardelli, M. (2013b). Agricultural waste-based composts exhibiting suppressivity to diseases caused by the phytopathogenic soil-borne fungi (Rhizoctonia solani) and (Sclerotinia minor), Applied Soil Ecology, 65, 43-51. https://doi.org/10.1016/j.apsoil.2013.01.002

[53] Pane, C., Celano, G., Piccolo, A., Villecco, D., Spaccini, R., Palese, A.M. \& Zaccardelli, M. (2015). Effects of on-farm composted tomato residues on soil biological activity and yields in a tomato cropping system, Chemical and Biological Technologies in Agriculture, 2, 4-16 (13 pages). https://doi.org/10.1186/s40538-014-0026-9

[54] Pane, C., Palese, A.M., Spaccini, R., Piccolo, A., Celano, G. \& Zaccardelli, M. (2016). Enhancing sustainability of a processing tomato cultivation system by using bioactive compost teas, Scientia Horticulturae, 202, 117-124. https://doi.org/10.1016/j.scienta.2016.02.034

[55] Rebollido, R., Martinez, J., Aguilera, Y., Melchor, K., Koerner, I. \& Stegmann, R. (2008). Microbial populations during composting process of organic fraction of municipal solid waste, Applied Ecology and Environmental Research, 6(3), 61-67. https://doi.org/10.15666/aeer/0603_061067

[56] Reddy, K.S., Kumar, N., Sharma, A.K., Acharya, C.L. \& Dalal, R.C. (2005). Biophysical and sociological impacts of farmyard manure and its potential role in meeting crop nutrient needs: a farmers' survey in Madhya Pradesh, India, Australian Journal of Experimental Agriculture, 45(4), 357-367. https://doi.org/10.1071/EA03225

[57] Ryckeboer, J., Mergaert, J., Vaes, K., Klamer, S., De Clercw, D., Coosemans, J., Insam, H. \& Swings, J. (2003). A survey of bacteria and fungi occurring during composting and self-heating processes, Annals of Microbiology, 53(4), 349-410.

[58] Said-Pullicino, D. \& Gigliotti, G. (2007). Oxidative biodegradation of dissolved organic matter during composting, Chemosphere, 68(6), 10301040. https://doi.org/10.1016/j.chemosphere.2007.02.012

[59] Saint-Joly, C., Peyre, A., Bochu, J.L. \& N'Dao, O. (1989). Pressure losses during ventilation of manure, Biological Wastes, 30(2), 123-132. https://doi.org/10.1016/0269-7483(89)90066-9

[60] Stentiford, E.T. (1996). Composting control: Principles and practice, in De Bertoldi, M., Sequi, P., Lemmes, B. and Papi, T. (Eds.), The Science of Composting, , Springer Science + Business Media Dordrecht, UK, 49-59.

[61] Sullivan, D.M., Costello, R. \& Digger, R. (2010). Breaking it down: Growers can get the most value from their compost by having it analyzed first, From Forest Nursery Notes, 54(10), 41-46.

[62] Tiquia, S.M. (2005). Microbiological parameters as indicators of compost maturity, Journal of Applied Microbiology, 99(4), 816-828. https://doi.org/10.1111/j.1365-2672.2005.02673.x 
[63] Venglovsky, J., Sasakova, N., Vargova, M., Pacajova, Z., Placha, I., Petrovsky, M. \& Harichova, D. (2005). Evolution of temperature and chemical parameters during composting of the pig slurry solid fraction amended with natural zeolite, Bioresource Technology, 96, 181-189. https://doi.org/10.1016/j.biortech.2004.05.006

[64] Verkhovtseva, N.V., Osipov, G.A., Bolysheva, T.N., Kasatikov, V.A., Kuzmina, N.V., Antsiferova, E.J. \& Alexeeva A.S. (2002). Comparative investigation of vermicompost microbial communities, in Insam, $\mathrm{H}$, Riddech, $\mathrm{N}$ and Klammer, $\mathrm{S}$ (Eds.), Microbiology of composting, Springer, Berlin, Heidelberg, 99-108.

[65] Wilson, G.C.S. (1984). The physico-chemical and physical properties of horticultural substrates, Acta Horticulturae, 150, $19-32$. https://doi.org/10.17660/ActaHortic.1984.150.1

[66] Wong, J.W.C, Mak, K.F., Chan, N.W., Lam, A., Fang, M., Zhou, L.X., Wu, Q.T. \& Liao, X.D. (2001). Co-compost of soybean residues and leaves in Hong Kong, Bioresource Technology, 76, 99-106. https://doi.org/10.1016/s0960-8524(00)00103-6

[67] Zotarelli, L., Zatorre, N.P., Boddey, R.M., Urquiaga, C., Jantalia, C.P., Franchini, J.C. \& Alves, B.J.R. (2012). Influence of no-tillage and frequency of a green manure legume in crop rotations for balancing $\mathrm{N}$ outputs and preserving soil organic $\mathrm{C}$ stocks, Field Crops Research, 132, 185195. https://doi.org/10.1016/j.fcr.2011.12.013

68] Zucconi, F., Monaco, A., Forte, M. \& De Bertoldi, M. (1985). Phytotoxins during the stabilization of organic matter, in Gasser, JKR (Eds.), Composting of Agricultural and Other Wastes, Elsevier Applied Science Publishers, Barking, London, 73-86.

69] Zucconi, F. \& De Bertoldi, M. (1987). Compost specifications for the production and characterization of compost from municipal solid waste, in De Bertoldi, M, Ferranti, MP, L'Hermite, P and Zucconi F (Eds.), Compost: Production, quality and use, Elsevier, Barking, London, 30-50. 